\title{
SEMINARJA O METODAH KORPUSNEGA IN EKSPERIMENTALNEGA JEZIKOSLOVJA V BEOGRADU IN ZAGREBU
}

\section{Jaka ČIBEJ}

Filozofska fakulteta Univerze v Ljubljani

\section{Iza ŠKRJANEC}

Ljubljana

Čibej, J., Škrjanec, I. (2016): Seminarja o metodah korpusnega in eksperimentalnega jezikoslovja $v$ Beogradu in Zagrebu. Slovenščina 2.o, 4 (1): 15-19.

DOI: http://dx.doi.org/10.4312/slo2.0.2016.1.15-19.

\section{UVOD}

Junija 2016 sta v Beogradu in Zagrebu potekala seminarja z naslovom Empirični podatki $v$ raziskovanju jezika: viri in metode,${ }^{1} \mathrm{ki}$ ju je organizirala Regionalna iniciativa za jezikovne podatke (ReLDI). Gre za dveletni projekt, v katerem sodelujejo institucije iz Švice, Srbije in s Hrvaške, financira pa ga Švicarski nacionalni sklad za znanost v okviru programa SCOPES. Glavni cilji iniciative so gradnja in distribucija jezikovnih virov ter orodij za podporo empiričnih raziskav hrvaškega in srbskega jezika, organizacija didaktičnih aktivnosti za raziskovalce ter vzpostavitev regionalne skupnosti raziskovalcev, ki bodo podatke in orodja uporabljali pri raziskovalnem ter pedagoškem delu. V sklopu zadnjega cilja sta bila organizirana tudi seminarja ReLDI. Seminarja v Beogradu se je udeležil Jaka Čibej (Filozofska fakulteta Univerze v Ljubljani), seminarja v Zagrebu pa Iza Škrjanec (študentka Mednarodne podiplomske šole Jožefa Stefana).

\footnotetext{
${ }_{1}^{1}$ Program na seminarjih je potekal v srbskem oz. hrvaškem jeziku, v poročilu pa naslove predavanj navajamo v slovenščini. Izvirni naslovi so razvidni iz programa na uradni spletni strani projekta ReLDI v zavihku »Seminari«.
} 


\section{PROGRAM}

Na obeh seminarjih je bil izveden sklop uvodnih predavanj, seminarja pa sta se razlikovala predvsem v vabljenih predavanjih. Glavna predavanja so izvedli vodja iniciative Tanja Samardžić (CorpusLab, Univerza v Zürichu), koordinator iniciative ReLDI za Hrvaško Nikola Ljubešić (Inštitut »Jožef Stefan« in Filozofska fakulteta Univerze v Zagrebu) ter koordinatorka iniciative ReLDI za Srbijo Maja Miličević (Filološka fakulteta Univerze v Beogradu). Poleg eno- ali enoinpolurnih predavanj o metodah korpusnega in eksperimentalnega jezikoslovja sta seminarja zajemala tudi praktično delo s korpusnimi viri za srbščino in hrvaščino (korpusa $\mathrm{srWaC}$ in hrWaC) v različnih konkordančnikih (SketchEngine, NoSketchEngine ter konkordančnik za korpusa srWaC in hrWaC, ki so ga izdelali v okviru iste iniciative). Predstavljena so bila tudi nekatera druga orodja, ki so bila razvita $\mathrm{v}$ okviru iniciative (npr. oblikoskladenjski označevalnik besedil in rediakritizator za hrvaščino in srbščino - obe orodji sta prilagojeni tudi za slovenščino), ter instrumenti za jezikoslovne eskperimente, npr. vprašalniki za ocenjevanje slovnične sprejemljivosti jezikovnih pojavov. Na obeh seminarjih je bil del dneva namenjen tudi skupinskemu delu, pri katerem so udeleženci s pomočjo korpusnih virov in $\mathrm{z}$ metodami eksperimentalnega jezikoslovja zasnovali eksperiment na temo izbranega jezikovnega problema ter interpretirali podatke, izluščene iz korpusov. Izsledke so predstavili v zaključnem delu seminarja, sledila pa je še diskusija. V nadaljevanju poročila so predstavljene delavnice in vabljena predavanja vsakega od seminarjev.

\subsection{SEMINAR V BEOGRADU}

Seminarja v Beogradu, ki je potekal med 2. in 5. junijem 2016 na Filološki fakulteti Univerze v Beogradu, se je udeležilo 30 študentov in raziskovalcev iz Srbije in s Hrvaške ter iz Makedonije, Bosne in Hercegovine ter Slovenije.

Poleg osnovnega programa je seminar zajemal tudi vabljena predavanja. Pri 
predavanju z naslovom Kombiniranje korpusnega in eksperimentalnega pristopa $v$ razumevanju morfološke kompleksnosti jezika (Dušica Filipović Đurđević, Univerza v Novem Sadu in Univerza v Beogradu) so se udeleženci seznanili z možnostmi proučevanja morfologije tako z vidika korpusnega kot eksperimentalnega jezikoslovja, pri predavanju z naslovom Ocene jezikovne sprejemljivosti: tehnika ocenjevanja velikosti $v$ primerjavi s tradicionalnimi tehnikami (Tihana Kraš, Univerza na Reki) pa predvsem z zasnovanjem eksperimentov za proučevanje jezikovne sprejemljivosti.

Predstavljeni so bili tudi trije sorodni projekti, in sicer Digitalizacija srbskih službenih novic 1813-2013 (Svetlana Albijanić, Službeni glasnik), Eksperimentalna morfosintaksa južnoslovanskih jezikov (EMSS) (Ivana Mitić, Univerza v Nišu) in Projekt AThEME - Bilingualism Matters@Rijeka: pridobivanje in popularizacija znanstvenih spoznanj o večjezičnosti (Siniša Smiljanić, Univerza na Reki).

\subsection{SEMINAR V ZAGREBU}

Seminar v Zagrebu je potekal med 27. in 30. junijem 2016 na Filozofski fakulteti Univerze v Zagrebu, udeležilo pa se ga je 30 študentov in raziskovalcev $\mathrm{s}$ Hrvaške, iz Srbije, Bosne in Hercegovine ter Slovenije.

Poleg glavnih izvajalcev so zanimive raziskave in sorodne projekte predstavili še gostujoči predavatelji: Anita Peti-Stanić (Filozofska fakulteta Univerze v Zagrebu), ki je govorila o eksperimentalni morfosintaksi južnoslovanskih jezikov, Darja Fišer (Filozofska fakulteta Univerze v Ljubljani in Inštitut »Jožef Stefan«), ki je predstavila projekt JANES, Simon Krek (Inštitut »Jožef Stefan« in Filozofska fakulteta Univerze v Ljubljani), ki je predaval o zasnovi spletnega slovarja slovenskega jezika, Gordana Hržica (Fakulteta za izobraževanje in rehabilitacijo Univerze v Zagrebu), ki je govorila o korpusih govorjenega jezika, in Nikola Dobrić (Inštitut za anglistiko in amerikanistiko Univerze Alpe-Adria $\mathrm{v}$ Celovcu), ki je predaval o korpusu besedil učencev in dijakov, v katerem so 
označene jezikovne napake.

\section{POMEN SEMINARJEV}

Seminarja sta bila med udeleženci zelo pozitivno sprejeta. Še posebej poudarjena je bila raznolikost obravnavanih tem, zaradi katere sta bila seminarja primerna za študente z različnih področij. Udeleženci so se ne glede na svoje predznanje z lahkoto seznanili z novimi metodami, pohvaliti pa je treba tudi uravnoteženo dinamiko pri delu v skupinah, saj so pri njem sodelovali študenti in raziskovalci $\mathrm{z}$ različnih področij in $\mathrm{z}$ različnimi nivoji predznanja. Nenazadnje velja omeniti tudi, da je seminar ReLDI odlična priložnost za navezovanje stikov z raziskovalci s področja bivše Jugoslavije in zato ponuja dobro podlago za nadaljnje skupne raziskave slovenščine in njej sorodnih jezikov.

Organizatorji načrtujejo še dva podobna seminarja v istih dveh mestih: prvega v januarju 2017 (Beograd), drugega (Zagreb) pa februarja v istem letu. 


\section{SEMINARS ON CORPUS AND EXPERIMENTAL LINGUISTIC METHODS IN BELGRADE AND ZAGREB}

To delo je ponujeno pod licenco Creative Commons: Priznanje avtorstva-

Deljenje pod enakimi pogoji 4.o Mednarodna.

This work is licensed under the Creative Commons Attribution-ShareAlike 4.0

International.

https://creativecommons.org/licenses/by-sa/4.o/

(c) 0 